\title{
BUSINESS ETHICS COURSE ON STUDENT MORAL REASONING
}

\author{
Ascaryan Rafindaa ${ }^{1,2 *}$, Tímea Gál ${ }^{2}$, Putri Purwaningtyas ${ }^{1}$ \\ ${ }^{* 1}$ Faculty of Economics and Business, Universitas Jenderal Soedirman, Indonesia, \\ ${ }^{2}$ Faculty of Economics and Business, University of Debrecen, Debrecen, Hungary \\ ascaryan.rafinda@yahoo.com \\ gal.timea@econ.unideb.hu \\ putri.purwaningtyas@gmail.com
}

\begin{abstract}
This research aims to identify and measure the effectiveness of business ethics courses on student Moral Reasoning. In-depth interview and a pilot test were conducted to examine the understandability of the experimental instrument. Quasi-experimental methods were conducted on students who join a business ethics course. One hundred twenty-two participants were valid from the manipulation check of pre-test and post-test. Paired T-Test was used to test the score between pre-test and post-test. Moral reasoning was measured using a defining issue test (DIT) to categorise High and Low Moral Reasoning on Participants. The result shows no difference in moral reasoning score between pre-test and post-test on a student who joins the business ethics course. This study finds that student moral reasoning does not improve by joining a business ethics course at university. These results imply that we should evaluate and re-examine the business ethics course syllabus for future research.
\end{abstract}

Keywords: Business Ethics Course, Quasi-Experimental, Moral Reasoning.

JEL classification: 123, P36.

\section{Introduction}

Unethical individual behaviour will be triggered based on personal moral knowledge. Individuals with higher moral knowledge will be able to deal with situations that expose an ethical dilemma. Gross (2009) and Tett (2009) found that corporate greed is the source of the problem of the global crisis in the world, they suggest that the success and sustainability of business lie at the foundation named ethics. Several prior research found the role of ethical value on unethical behaviour (see research Abdolmohamamadi and Sultan, 2002; Ponemon and College, 1992; Xu and Ziegenfuss, 2008; Uddin and Gillet, 2002 and Rafinda, Arofah, Mustafa, Ompusunggu, 2015).

Managers believe that the workplace is not the right place for someone to learn about ethics; even the manager hopes that someone becomes an employee already have a robust ethical value (Sigurjonsson, 2014). It is implied that business school has the responsibility in educating the attitude of prospective employees for a company is not just merely transferring business knowledge, but have been able to reach the stage of internalisation of ethical values that are taught.

The business school has become an institution that has been mentioned many times by some parties that transfer of knowledge about ethical leadership (Alsop, 2007; Etzioni, 2002; Hosmer, 1988). One of the goals of business ethics courses at the undergraduate level business administration and master of business administration is to develop moral consciousness, and problem-solving that require ethical considerations (Acevedo, 2013).

\footnotetext{
* Corresponding author: Ascaryan Rafinda
} 
Moral consciousness is the individual's ability to identify a case requiring an ethical decision or not. This study aims to identify the impact of a business ethics course on the internalisation of moral values by measure the moral reasoning level on the college student. This research is necessary because of several factors: 1) Various organizations believe that the internalization of ethical understanding will not occur in the workplace, but occurs when a person is studying, 2) The business school is one of the institutions that are responsible for extending values of ethics to students on campus, 3) Student ethics values must be taught at the university through business ethics course. This research aimed to test the effectiveness of business ethics courses for students by measuring their moral reasoning.

\section{Literature review}

\subsection{Business Ethics Education}

The decisions taken on the managerial level in an organisation is often a decision that requires ethical considerations. Manager's ability to consider ethical business decisions becomes mandatory in an organisation. Formal education in the field of ethics shows that it can raise awareness of ethics, ethical judgment and commitment to ethical values, especially in adolescents who have the ability to logic and make decisions that require action novelty (Duska, 1991; Glenn, 1992; James \& Cohen, 2004; Piper, Gentile, \& Parks, 1993; Rest, 1988; Stead \& Miller, 1988; Williams \& Dewett, 2005).

Business ethics education is the responsibility of the business school. The integration of ethics on business school course needs to be done continuously (Suryaningrum, Subroto, Sutrisno \& Rahman, 2015). This is because people get ethics education only on academic education, and cannot obtain when he is already at the workplace. International accreditation agency such as AACSB (Association to Advance Collegiate School of Business) suggests business schools to pay attention to the subject of business ethics curriculum. However, there is no minimum standards and raw publication for governing how the curriculum should be on business ethics. This makes the curriculum of business ethics courses have variation in implementation and have various impact on student perception on ethical value.

\subsection{Moral Reasoning}

There are several stages of individuals to act ethically according to Cohen and Bennie (2006) and Jones and Washington (1991). First, the individual must have an ethical awareness to identify whether it faces a situation associated with ethical issues. The second stage is that the individual will make an ethical judgment(s) on the situation and determine the various alternative measures to be taken to deal with the situation. The third stage, an individual will choose alternative actions and deal with the situation. The fourth stage, the individual decides behaviour for what has to be considered from the beginning to the end to confront the ethical dilemma situation.

John Dewey, in Kohlberg (1975), postulates three levels of moral development. First, pre-moral in this case motivated individuals' behaviour as a biological and social impulse. Second, the conventional in this case when the individual behaves in the hope of the acceptance to a particular group or community. Third, post-moral, this stage individual will behave ethically automatically because of their self-belief. Jean Piaget (1932), in Kohlberg (1975), develops the definition of level moral reasoning with interviews and observations method to children. Piaget defines three levels of moral reasoning. The first is the stage of pre-moral when the individual does not have a sense of want to obey the rules. Second, the heteronomous is when the individual obeys the regulation because the individual abides by the rules and penalties are subject to the authority of the rule. Third, the autonomous is the individual behaviour based on reciprocity obtained for their behaviour. 
Kohlberg in 1955 defined and validated the longitudinal and cross-cultural moral reasoning levels developed by Dewey and Piaget (Kohlberg, 1975). Kohlberg resulted from research in 1955 classifying the underlying reasoning of individuals to an event considered ethical or unethical; there are three levels. The first level is the pra conventional when individuals behave ethically because they do not want to be punished and to benefit themselves for such behaviour. The second level is called conventional that is when individuals behave ethically because of the desire social acceptance in the environment or an agreement established norm within a group. The third level is called post-conventional when individuals behave ethically because it follows the principle of personal ethics and follows the universally accepted principle. The higher the individual's understanding of the moral, the higher the moral level is. Individuals who have high moral understanding will tend to behave ethically as it may consider various alternative actions (ethical-takes) when faced with situations that pose ethical dilemmas.

Rest developed the instrument of Defining Issues Test (DIT) to measure the level of individual moral reasoning. DIT already used in a wide variety of research on examining the life and experience of a college student (Patricia \& Mayhew, 2002). Rest (1999) tested the validity of the two types of Defining Issues Test (DIT). DIT2 has two differences compared to DIT1. The first difference, the fewer number of cases in the form of: 1) "famine", 2) "reporter", 3) "school board", 4) "cancer", and 5) "demonstration". Secondly, DIT1 measured using p-score while DIT2 measured using N2. Results from these studies indicate that DIT2 has higher validity than DIT1. Although the results showed more valid, in conclusion, DIT2 instrument still needs verification because it is only tested with 200 students and disproportionate when compared with DIT1 that has been used by hundreds of researchers with a total sample of approximately 500,000 participants. This study used DIT1 because it has validating by hundreds of researchers in measuring the individual's moral reasoning.

\subsection{Business Ethics Education Relationship with Moral Reasoning}

This study aims to identify the impact of business ethics courses taught in Indonesia on student moral reasoning. As one of the mandatory courses in Indonesia Business school, business ethics should have a good impact on student. Business ethics courses become the foundation for business schools to educate students on moral values. This makes the business ethics course has a vital role in giving the necessary foundation of ethical values for the prospective employee. Moral reasoning of students will be measured before getting a business ethics course and after getting a business ethics course. During the course, students acquire knowledge about business ethics, with a comprehensive knowledge of business ethics and study the various cases relating to business ethics. It can strengthen the understanding of ethical values in business. Someone who has a broader knowledge of business ethics will have a better ability to do moral reasoning when facing a situation that arises ethical dilemmas. Based on these arguments, the hypothesis is:

H1: Students moral reasoning will improve after participating in business ethics courses on campus.

\section{Research Method}

\subsection{Data collection}

The data in this study was taken by using the experimental method. Participants were students who take a business ethics course at several universities in Indonesia. Universities in Purwokerto, Malang, Makassar and Kupang were collected for sampling in this study. The four cities can be the student representative on the three Indonesian regions (West, Central and East), public and private University and big, medium and small University, so the target population in this study were students throughout Indonesia. 


\subsection{Business Ethics Education}

Business ethics education is the manipulation variable. Participants are given a business ethics course for one semester and then analysed the impact of the course on the level of moral reasoning. Participants are students majoring in accounting who are taking a business ethics course at the college. Even the lecturer is different between four institutions, but they are using the same syllabus and reference book when conducting the business ethics course.

\subsection{Moral Reasoning}

Participants were asked to choose action on a case and asked to rank the reasons for these choices. Six scenarios provided by Rest (1986) to measure the level of moral reasoning of individuals, there are: 1) Heinz and the Drugs, 2) the Escaped Prisoner, 3) the Newspaper, 4) The Doctor's Dilemma, 5) Webster and 6) Student Take Over, This study uses three scenarios as a short form of DIT1. This is done with the hope of not reducing the concentration of the participants during the experiment. This is because, according to Rest (1986) the time required to complete the six scenarios about 30-40 minutes, while the short form requires 20-30 minutes. Time is too long to worry about the task to reduce the level of concentration and seriousness of the participant. Three scenarios were developed by Rest (1986) which is short forms of DIT 1, there are: 1) Heinz and the Drugs, 2) the Escaped Prisoner, and 3) the Newspaper. A 12 statement followed each scenario as a participant consideration in the decision on the scenario. Participant asks to choose between three actions in one case, and they have to give the reason why choose that option. For example, Heinz and the Drugs case ask the participant to choose between steal the drug or not. The Heinz is the person that his wife was dying because of a rare disease, and one pharmacy already found the cure. The pharmacy wants to get a massive profit from the invention, so the pharmacy sells at a high price. Heinz cannot afford the prize, but the wife dying and need the drug immediately. Then participant ask which action Heinz should do? A) steal the drug, b) cannot decide, c) not steal the drug. After that participant has to rate 12 statement why they choose the action. DIT instrument developed by Rest (1986) can measure a person's proximity to the moral level to the third level (post-conventional). The closer to the third level shows the level of higher moral reasoning.

Participants were measured using the DIT level of moral reasoning based on p-score (post-conventional score). The short form has a correlation of 0.93 with an instrument that uses six scenarios DIT (Rest, 1986). It shows the short form has a similar property to the form of the six scenarios (Rest, 1986). The classification of participants to be included in the category of low level and high moral by using the median or middle value of the $\mathrm{p}$-score set by Rest (1986) as the theoretical limit.

\subsection{In-Depth Interview Research Instruments}

In-depth interview was conducted in two stages. First, discussions were made with some of the lecturers who have been directly involved in field experiments and understand the experimental instrument validation techniques. Two senior lecturers who are experts on experimental and behavioural accounting were invited as the expertise of moral reasoning instrument. The second stage by sending the instrument to some lecturer of business ethics class that had been used as a sample. After the lecturers read and understood the instrument, the researchers and lecturers held an online conference using Skype. Five people were involved and provided input to the instrument to be used. Results of the discussion online and offline, there are several suggestions in the writing instrument that make it easier to understand by participants. Several manipulation checks added to ensure that participants understood the treatment according to the study. 


\subsection{Pilot Tests}

Instruments that have been discussed in the in-depth interview get another input from several parties after conducted the pilot test. Participants of the pilot test were students of the Faculty of Economics and Business UNSOED. Thirty-five participants following the pilot test on the 60 minutes experiment. Participants were students who were voluntarily following the pilot testing of this research. Results of the pilot test were carried out, 32 participants successfully passed from an experiment by answer the manipulation check correctly, while 3 participants did not pass because of the wrong answer on the manipulation check. After participants finished filling the research instruments, researchers gave participants the opportunity to provide comments and suggestions related to the understanding given instrument. The discussion results showed that $92 \%$ of participants easily understood the questions in the instruments and there is some sentences correction to increase the understandability of the instrument.

\subsection{Implementation of Experiments}

Pre-test and Post-test were conducted to obtain the level of moral reasoning of students before and after the business ethics course. The pre-test was done before the first session of the course is conducted, and Post-test was done just before final exams performed. Students were asked to fill out the instrument defining issue test (DIT) by answering three cases that have been provided. We minimise the occurrence of threat that could arise due to differences in sampling time and classroom conditions; it has been agreed upon several matters related to sampling procedures research. Some things that concern guiding field experiment, there are: 1) the experiment must be carried out before 9 o'clock in the morning, 2) the room must be comfortable and silent, 3) participants must be in no hurry and follow experiments voluntarily and 4) participants are willing to follow the experiment post-test when they passed pre-test experiments.

Implementing pre-test experiments performed with different days depending on the condition of the commencement of lectures at any university in the research samples. Here is the tabulation of time and number of participants pre-test from four different locations:

Table 2: Participant distribution

\begin{tabular}{lccc}
\hline \multicolumn{1}{c}{ City } & $\begin{array}{c}\text { Number of } \\
\text { Participants }\end{array}$ & $\begin{array}{c}\text { Experiment } \\
\text { Schedule }\end{array}$ & Passed Pre-test \\
\hline Purwokerto & 37 & $08.00-09.00$ & 34 \\
Malang & 35 & $08.30-09.30$ & 32 \\
Makasar & 36 & $09.00-10.00$ & 31 \\
Kupang & 28 & $08.00-09.00$ & 25 \\
Total Participants & $\mathbf{1 3 6}$ & & $\mathbf{1 2 2}$ \\
\hline
\end{tabular}

Experimental stages in this study are: 1) Participants are invited to one day before the first meeting of the business ethics course, 2) Participants were not told that the experiment is related to the subject of business ethics, it is to reduce probability the social desirability bias, 3) Participants were asked in advance their willingness to participate in this study, 4) participants who are willing to participate, remain in class for 45-60 minutes, 5) Participants described the phases of the experiment to be carried out and assuredness confidentiality identity, 6) Participants given instrument with stationery to work on the case are provided in the instrument, 7) Participants fill and finish with a time of 30-45 minutes, 8) Participants fill out the agreement to follow the next session (session post-test) 9) Participants leave the room after all the experiments finished. 
Post-test experiments carried out shortly before the end of term exams. Date of implementation varies because each university has a different academic calendar. Although it has a different date but is still among the experimental implementation in June and July 2018, the timing of the still performed before 09:00 am, so expect the condition between the test group is not too different in terms of stamina, environmental conditions and there is no noise. All participants who pass the stage pre-test 122 participants present and can take the test post-test implemented.

\subsection{Experimental Procedure}

This research experiment using a single group design with pre and post-test examination. Participants were students who are taking a business ethics course at the faculty of Economics and Business at several universities in Indonesia. This experiment is quasi-experimental. Participants get a manipulation in the form class of business ethics courses that have been taught by lecturers. Researchers will give moral reasoning instrument to the participants at the beginning of the course and will be measured again at the end of the course.

Table 1: Experimental Design Research

\begin{tabular}{|c|c|c|}
\hline Pre-test & Manipulation & Post-test \\
\hline O1 & $\mathrm{X}$ & $\mathrm{O} 2$ \\
\hline
\end{tabular}

\subsection{Data analysis and hypothesis testing}

The analysis was done by comparing the moral reasoning score between pre-test and post-test group. This analysis was examined to identify the effectiveness of business ethics education. The hypothesis supported when there is found a significant increase in the level of participant moral reasoning. However, if it does not differ significantly, then the hypothesis is not supported by the data.

\section{Results and Discussion}

Data from this study is obtained by performing a quasi-experimental. A quasi-experimental study was conducted by taking samples in the faculty of economics and business students who are taking a business ethics course at several universities in Indonesia. Four cities were targeted for a sampling of this research; there are Purwokerto, Malang, Makasar and Kupang. The towns became the four representatives of western Indonesia, Central and East.

\subsection{Experiment results}

Experiments were conducted in two sessions: pre-test and post-test with manipulation in the form of business ethics courses. The result of this experiment is the moral reasoning level of the student. The different paired t-test did the data analysis. Two experimental groups were compared to the value of moral reasoning before and after the manipulation is done. The statistic descriptive of the table of students' moral reasoning before and after manipulation is shown in Table 3. 
Table 3: Statistic Descriptive

\begin{tabular}{|l|c|c|}
\hline Statistic Descriptive & Pre-test & Post-test \\
\hline Mean & 39.52 & 39.39 \\
\hline Standard Error & 0.31 & 0.26 \\
\hline Median & 39.00 & 39.00 \\
\hline Mode & 36.00 & 40.00 \\
\hline Standard Deviation & 3.39 & 2.84 \\
\hline Sample Variance & 11.47 & 8.08 \\
\hline Kurtosis & -1.31 & -0.66 \\
\hline Skewness & 0.23 & 0.31 \\
\hline Range & 10.00 & 10.00 \\
\hline Minimum & 35.00 & 35.00 \\
\hline Maximum & 45.00 & 45.00 \\
\hline Sum & 4822.00 & 4806.00 \\
\hline Count & 122.00 & 122.00 \\
\hline Confidence Level(95,0\%) & 0.61 & 0.51 \\
\hline
\end{tabular}

Analysis of paired t-test was performed to compare the test results and the value of DIT on pre-test post-test. Paired t-test was conducted as using a subject with two treatments (pre-test and post-test). Here are the results of Paired t-test:

Table 4: The result of Paired Samples T-Test

\begin{tabular}{|c|c|c|c|c|c|c|c|c|c|}
\hline & 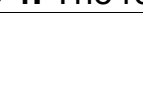 & \multicolumn{5}{|c|}{ Paired Differences } & $t$ & Df & $\begin{array}{c}\text { Sig. } \\
\text { (2-tailed) }\end{array}$ \\
\hline & & \multirow[b]{2}{*}{ Mean } & \multirow{2}{*}{$\begin{array}{c}\text { Std. } \\
\text { Deviation }\end{array}$} & \multirow{2}{*}{$\begin{array}{l}\text { Std. } \\
\text { Error } \\
\text { Mean }\end{array}$} & \multicolumn{2}{|c|}{$\begin{array}{l}\text { 95\% Confidence } \\
\text { Interval of the } \\
\text { Difference }\end{array}$} & & & \\
\hline & & & & & Lower & Upper & & & \\
\hline $\begin{array}{l}\text { Pair } \\
1\end{array}$ & $\begin{array}{l}\text { MR_1- } \\
\text { MR_2 }\end{array}$ & .13115 & 2.54854 & .23073 & -.32565 & .58795 & .568 & 121 & .571 \\
\hline
\end{tabular}

The result of the paired t-test showed that the experimental results between pre-test with after-test showed no significant difference. It can be seen in the column Sig (2-tailed) of 0.571 which has a score above 0.05 .

\section{Conclusion}

The purpose of this study is to verify the usefulness of a business ethics class at an Indonesia business school. The research sample who took from various cities in Indonesia that have been able to represent the target population. Samples from western Indonesia, central and eastern used to consider the heterogeneity of the research sample.

The analysis showed that there was no difference in the value of the level of moral reasoning before classes students business ethics, and after following a business ethics class. It shows that business ethics class has not been able to improve students' ability to perform moral reasoning. As the student does not improve their moral reasoning, it implies that they do not internalise how to think ethically. Moral reasoning explains the ability of the student to related the action into moral value. When they are not improving, it means, they still have the same moral reasoning value. 
Based on the findings of this study need to be done a variety of advanced research that aims to re-examine the effects of business ethics classes on a variety of factors such as moral awareness and moral sensitivity. Besides that, it is necessary also to re-examine the material and syllabus used by the lecturer on classes. Another finding in this research is the score of $p$-value in this sample relatively already high, then that is might be another reason why moral reasoning did not improve during the study.

Recommendations based on the findings of this study are to evaluate the need for educational institutions on the content of business ethics courses that are taught to students. For other agencies, with proven that moral reasoning ability students do not improve through business ethics education, it should be noted that the recipient agencies college graduate employees are still required training on ethics and morals that should be emphasised.

\section{References}

Abdolmohammadi, M. and Sultan, J., 2002. Ethical Reasoning and the Use of Insider in Stock Trading Information. Journal of Business Ethics, 37 (2), pp. 165-173.

Acevedo, Alma., 2013. But, Is It Ethics? Common Misconceptions in Business Ethics Education. Journal of Education for Business, 88 (2), pp. 63-69.

Alsop, R., 2007. Talking B-school: Why teaching of ethics continues to be lacking. The Wall Street Journal, 7.

Cohen, J. R., and Bennie, N. M., 2006. The Applicability of a Contingent Factors Model to Accounting Ethics Research. Journal of Business Ethics, 68 (1), pp. 1-18.

Duska, R. F., 1991. What is the point of a business ethics course? Business Ethics Quarterly, 1 (4), pp. 335-354. doi: 10.2307/3857601.

Etzioni, A., 2002. When it comes to ethics, B-schools get an F. The Washington Post, B4. Glenn, J. R., 1992. Can a business and society course affect the ethical judgment of future managers? Journal of Business Ethics, 11 (3), pp. 217-223.

Gross, D., 2009. Dumb money: How our greatest financial minds bankrupted the nation. New York: Free Press.

James, H. S. Jr. and Cohen, J. P., 2004. Does ethics training neutralise the incentives of the prisoner's dilemma? Evidence from a classroom experiment. Journal of Business Ethics, 50 (1), pp. 53-61.

Jones, T. M., and Washington, U., 1991. Ethical Decision Making by Individuals in Organizations: An Issue-Contingent Model. Academy of Management Review, 16 (2), pp. 366-396.

Hosmer, L. T., 1988. Adding ethics to the business curriculum. Business Horizons, 31 (4), pp. 9-15.

Kohlberg, L., 1975. The Cognitive-Developmental Approach to Moral Education. A Special Issue on Moral Education, 56 (10), pp. 670-677.

.King, P.M. and Mayhew, M.J., 2002. Moral Judgement Development in Higher Education: Insights from the Defining Issues Test, Journal of Moral Education, 31 (3), pp. 247-270, DOI: 10.1080/0305724022000008106.

Piper, T.R., Gentile, M.C., and Parks, S.D., 1993. Can ethics be taught? Boston, MA: Harvard Business School.

Pojman, L. P., 2005. Ethics: Discovering right and wrong, (5th Ed.). Belmont, CA: Wadsworth.

Ponemon, L.A. and College, B., 1992. Auditor underreporting of time and moral reasoning: An experimental lab study. Contemporary Accounting Research, 9 (1), pp. 171-189

Rafinda, A., Arofah, T., Mustafa, R.M., Ompusunggu, H., 2015. Does ethics matter to predict Misreporting Behavior? Journal of Economics, Business, and Accountancy Ventura, 18 (1), pp. 133-144. 
Rest, J.R., 1986. Moral development: Advances in research and theory. New York: Praeger. Rest, J.R., 1988. Can ethics be taught in professional schools? The psychological research. Ethics Easier Said than Done, 1 (1), pp. 22-26.

Rest, J. R., Narvaez, D., Thoma, S.J. and Bebeau, M.J., 1999. DIT2: Devising and Testing a Revised Instrument of Moral Judgment. Journal of Educational Psychology, 91 (4), pp. 644-659.

Sigurjonsson, T. O., Vlad V. and Audur A A., 2014. The Role of Business School in Ethics Education in Iceland: The Managers' Perspective. Journal of Business Ethics, 122 (1), pp 25-38. https://doi.org/10.1007/s10551-013-1755-6.

Stead, B.A., and Miller, J.J., 1988. Can social awareness be increased through business school curricula? Journal of Business Ethics, 7 (7), pp. 553-560, https://doi.org/10.1007/BF00382603.

Suryaningrum, Diah Hari, Subroto, Bambang., T, Sutrisno and Rahman, Aulia, 2015 Empirical Analysis of Ethics Integration and Online Learning in Auditing Course on Ethical Decision Making: Further Evidence from Indonesia (April 2). Journal of Advanced Research in Business, Management, and Accounting, 1 (2), Available at: SSRN: https://ssrn.com/abstract=3031194.

Tett, G., 2009. Fool's gold: How the bold dream of a small tribe at J. P.Morgan was corrupted by all Street greed and unleashed a catastrophe. New York: Free Press.

Uddin, N, and Gillett, P.R., 2002. The effects of moral reasoning and self-monitoring on CFO intentions to report fraudulently on financial statements, Journal of Business Ethics, 40 (1), pp. 15-32.

Williams, S. D., and Dewett, T., 2005. Yes, you can teach business ethics: A review and research agenda. Journal of Leadership \& Organizational Studies, 12, pp. 109-120.

$\mathrm{Xu}, \mathrm{Y}$ and Ziegenfuss, D.E., 2008. Reward Systems, Moral Reasoning, and Internal Auditors' Reporting, Wrongdoing. Journal of Business and Psychology, 22 (4), pp. 323-331, http://link.springer.com/10.1007/s10869-008-9072-2.

\section{Bio-note}

Ascaryan Rafinda is a PhD student at Károly Ihrig Doctoral School of Management and Business, the University of Debrecen in Hungary. He also a lecturer at Faculty of Economics and Business, Universitas Jenderal Soedirman, Indonesia. His research is focused on financial behaviour and education.

Tímea Gál is an assistant professor of Marketing and Trade Department, University of Debrecen in Hungary. Her research field includes business and management.

Putri Purwaningtyas is a research assistant at Faculty of Economics and Business Universitas Jenderal Soedirman, Soerdiman. Her research field is business and management. 